\title{
Spectrophotometric Determination of Valacyclovir in Pharmaceutical Formulations
}

\author{
G. SRIHARI ${ }^{\mathrm{a}}$, N. RAMI REDDY ${ }^{\mathrm{a} *}$, K. NAGARAJA SETTY ${ }^{\mathrm{b}}$ and I.E. CHAKRAVARTHI ${ }^{\mathrm{c}}$ \\ ${ }^{a}$ Department of Chemistry, S.B.S.Y.M. Degree College, Kurnool (Dt), Andhra Pradesh, India \\ ${ }^{\mathrm{b}}$ Department of Chemistry, Government College for Men, Kurnool (Dt), Andhra Pradesh, India \\ ${ }^{\mathrm{c}}$ Department of Chemistry, Rayalaseema University, Kurnool (Dt), Andhra Pradesh, India \\ ramireddy65@gmail.com
}

Received 2 July 2012 / Accepted 28 July 2012

\begin{abstract}
A simple spectrophotometric method has been developed for the estimation of valacyclovir in pharmaceutical preparations. The method is based on the reaction of the valacyclovir with methanolic solution of para dimethyl amino benzaldehyde (PDAB) in acidic condition producing Schiff base having absorption maximum at $400 \mathrm{~nm}$. Beer's law is obeyed in the concentration of $50-250 \mu \mathrm{g} / \mathrm{mL}$ of valacyclovir. Statistical analysis proves that the proposed method is reproducible and selective for the estimation of valacyclovir in bulk drug and in its tablet dosage form.
\end{abstract}

Keywords: Spctrophotometry, Valacyclovir, para dimethyl amino benzaldehyde, Formulations

\section{Introduction}

Valacyclovir chemically, $L$-valine-2-[(2-amino-1, 6-dihydro-6-oxo-9-hipurin-9-yl) methoxy] ethyl ester is the $L$-valyl ester prodrug of the antiviral drug acyclovir that exhibits activity against herpes simplex virus types, 1 (HSV-1) and 2 (HSV-2) and vericellazoster virus. The mechanism of action of acyclovir involves the highly selective inhibition of herpes virus DN areplication, via enhanced uptake in herpes virus-infected cells and phosphorylation by viral thymidine kinase. The substrate specificity of acyclovir triphosphate for viral, rather than cellular, DNA polymerase contributes to the specificity of the drug. Valacyclovir is available as tablet dosage form in the market. Few spectrophotometrc methods ${ }^{1-4}$, HPLC methods ${ }^{5-11}$, RP-HPLC method ${ }^{12}$, are reported in the literature for the determination of valacyclovir in pharmaceutical formulations.

This paper describes a simple rapid, simple, sensitive and economical spectrophotometeric method for the determination of valacyclovir in commercial formulations. In the proposed method the valacyclovir is reacted with methanolic solution of para dimethyl amino benzaldehyde in acidic condition producing Schiff's base. Hence we have made an attempt to develop simple and sensitive spectrophotometric methods for the estimation of valacyclovir in bulk drugs and in pharmaceutical formulations. 


\section{Experimental}

All absorbance measurements were made on a Spectronic 1001 plus spectrophotometer (Milton Roy Company, USA) with $1 \mathrm{~cm}$ matched quartz cells. All the solutions were freshly prepared. All solvents and other chemicals used through this study were of analytical grade. Double distilled water was used throughout the investigation. $0.1 \mathrm{~N}$ sulphuric acid was prepared and standardized with standard procedure. $1 \% \mathrm{w} / \mathrm{v}$ of para dimethyl amino benzaldehyde in methanol was prepared.

\section{Preparation of standard solution}

A standard stock solution containing $1 \mathrm{mg} / \mathrm{mL}$ was prepared by dissolving $50 \mathrm{mg}$ of valacyclovir in $50 \mathrm{~mL}$ of methanol. From this, a working standard solution containing $100 \mu \mathrm{g} / \mathrm{mL}$ was prepared.

\section{Assay procedure}

Aliquots of valacyclovir ranging from $0.5-2.5 \mathrm{~mL}$ were transferred into a series of $10 \mathrm{~mL}$ volumetric flask. To each of the flask $1.0 \mathrm{~mL}$ of methanolic para dimethyl amino benzaldehyde and $1.0 \mathrm{~mL}$ of $0.1 \mathrm{~N} \mathrm{H} \mathrm{SO}_{4}$ were added and warmed on a water bath for $2 \mathrm{~min}$ and kept aside for $15 \mathrm{~min}$. at room temperature, the color development was developed. The volume was made up to mark with methanol. The absorbance of the dark green chromogen was measured at $400 \mathrm{~nm}$ against reagent blank. The amount of valacyclovir present in the sample was computed from calibration curve (Figure 1).

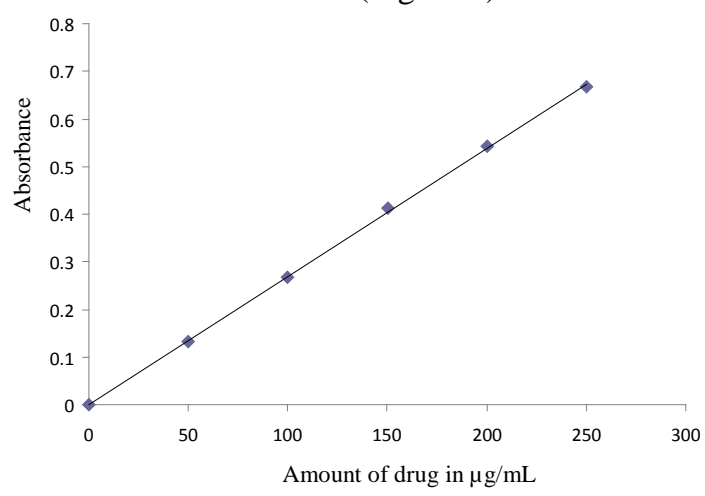

Figure 1. Calibration curve of valacyclovir

\section{Pharmaceutical formulations}

Twenty tablets containing valacyclovir were weighed and finely powdered. An accurately weighed portion of the powder equivalent to $50 \mathrm{mg}$ of valacyclovir was dissolved in a $25 \mathrm{~mL}$ of methanol and mixed for about 5 minutes and then filtered. Then the volume was diluted to $50 \mathrm{~mL}$ with methanol and analyzed as given under the assay procedure for bulk samples. The results are represented in Table 2.

\section{Recovery studies}

To ensure the accuracy and reproducibility of the results obtained, known amounts of pure drug was added to the previously analyzed formulated samples and these samples were reanalyzed by the proposed methods and also performed recovery experiments. The percentage recoveries thus obtained were given in Table 2 . 


\section{Results and Discussion}

In the proposed method the valacyclovir is reacted with methanolic solution of para dimethyl amino benzaldehyde in acidic condition producing Schiff base. The absorption of Schiff base was measured at $400 \mathrm{~nm}$ against reagent blank prepared similar manner omitting drug solution. The absorption spectra of dark green Schiff base were shown in Figure 2.

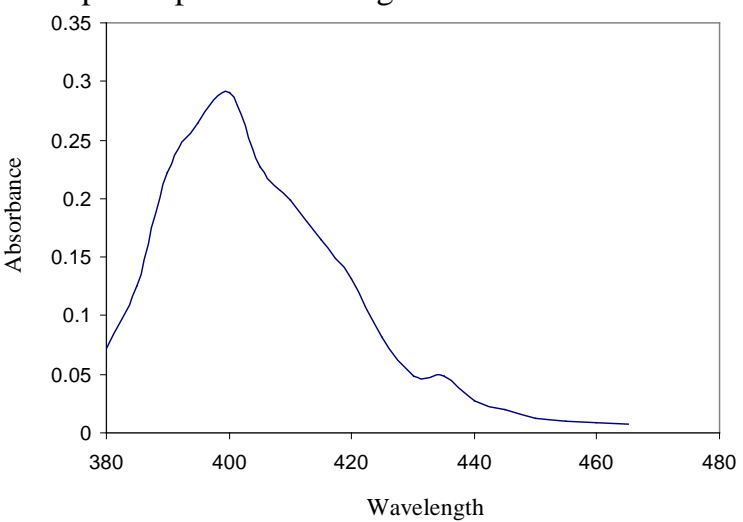

Figure 2. Absorption spectrum of valacyclovir condensed with PDAB at $440 \mathrm{~nm}$

The optimum conditions were established by varying one parameter at a time and keeping the others fixed and observing the effect on absorbance of chromogen for the proposed method. Statistical analysis was carried out and the results were found to be satisfactory. Recovery studies were close to $100 \%$ that indicates indicating good accuracy of the methods. The optical characteristics such as absorption maxima, Beer's law limits, molar absorptivity and Sandell's sensitivity are presented in Table 1 . The regression analysis using method of least squares was made for the slope (b), intercept (a) and correlation (r) obtained from different concentrations and results are summarized. The high molar absorptivities of the resulting colored complex indicate the high sensitivity of the method. The percent relative standard deviation, standard deviation and student's ' $t$ ' test values calculated from the five measurements of valacyclovir are presented in Table 2.

Table 1. Optical characteristics of proposed method

\begin{tabular}{lc}
\hline \multicolumn{1}{c}{ Parameters } & Proposed method \\
\hline$\lambda_{\max }, \mathrm{nm}$ & 400 \\
Beer's law limit, $\mu \mathrm{g} / \mathrm{mL}$ & $50-250$ \\
Molar absorptivity $\left(\mathrm{l} \mathrm{mole}{ }^{-1} \mathrm{~cm}^{-1}\right)$ & $3.6 \times 10^{3}$ \\
Sandell’s sensitivity & 0.361 \\
( $\mu \mathrm{g}$ cm-2 / 0.001 absorbance unit) & \\
Regression equation ( $\mathrm{Y}=\mathrm{a}+\mathrm{bC})$ & $\mathrm{Y}=0.0028 \mathrm{x}+0.003$ \\
Slope (b) & 0.0028 \\
Intercept (a) & 0.003 \\
Correlation coefficient $(\mathrm{r})$ & 0.9995 \\
\hline
\end{tabular}

Table 2. Assay of valacyclovir in tablets

\begin{tabular}{cccccc}
\hline Sample & $\begin{array}{c}\text { Labeled } \\
\text { amount, mg }\end{array}$ & $\begin{array}{c}{ }^{*} \text { Amount } \\
\text { found } \pm \text { S.D }\end{array}$ & \% Recovery & ${ }^{* *} \mathrm{t}_{\text {cal }}$ & \%RSD \\
\hline Tablet 1 & 500 & $500.06 \pm 0.34$ & 99.9 & 0.3878 & 0.0691 \\
Tablet 2 & 500 & $500.12 \pm 0.65$ & 100.02 & 0.4067 & 0.1319 \\
\hline
\end{tabular}


Relative standard deviation values and standard deviation were low that indicates the reproducibility of the proposed methods. In the student's 't' tests, no significant differences were found between the calculated and theoretical values of the proposed method at $95 \%$ confidence level. This indicated similar precision and accuracy in the analysis of valacyclovir in its tablets. The commonly used additives such as starch, lactose, titanium dioxide, and magnesium stearate do not interfere with the assay procedures.

\section{Conclusion}

The proposed method was found to be simple, rapid, sensitive, accurate, precise and economical and can be used for the routine quality control analysis of valacyclovir in industry, research laboratories and hospitals.

\section{References}

1. Ganesh M, Narasimha Rao C V, Saravana Kumar A, Kamalakannan K, Vinoba M, Mahajan H S and Siva Kumar T, E-J Chem., 2009, 6(3), 814-818.

2. Sudhakar Reddy J, Md. Maqsood Ahmed S, Chakravarth I E and Prabhavathi K, $J$ Chem Pharm Res., 2011, 3(4), 773-776.

3. Aswani Kumar C H, Anil Kumar T, Gurupadayya B M, Navya Sloka S and Rahul Reddy M B, Archives Appl Sci Res., 2010, 2(4), 278-287.

4. Srinu babu G, Sarat babu I, Kiran Kumar N, Yugandhar N M and Raju C H A I, Asian J Chem., 2007, 19, 1642.

5. $\quad$ Srinivasa Rao K and Sunil M, Int J Chem Tech Res., 2009, 1(3), 702-708.

6. Lakshmana Rao A, Rajeswari K R and Sankar G G, J Chem Pharm Res., 2010, 2(1), 280-282.

7. Jadhava A S, Patharea D B and Shingare M S, J Pharm Biomed Anal., 2007, 43, 1568.

8. Palacios M L, Demasi G, Pizzorno M T and Segall A I, J Liq Chromatogr Rel technol., 2005, 28, 751.

9. Patil D, Yeole P G, Manisha P and Wadher S, Int J Chem Tech Res., 2009, 1, 16.

10. Fish D N, Vidaurri V A and Deeter R G, Am J Health-System Pharm., 1999, 56, 1957.

11. Palacios M L, Demasi G, Pizzorno M T and Segall A I, J Liq Chromatogr Rel Technol., 2005, 28, 751.

12. Ayhan Savaser Cansel Ozkan Yalıcn, Ozkan Bengi Uslu Sibel and Ozkan A, J Liq Chromatogr Rel Technol., 2003, 26(11), 1755-1767. 